DOI: https://doi.org/10.32353/khrife.2.2020.33

УДК 343.98

\title{
Ю. Ю. Петришина,
}

науковий співробітник лабораторії будівельно-технічних досліджень

Національного наукового центру «Інститут судових експертиз

ім. Засл. проф. М. С. Бокаріуса», м. Харків, Україна,

ORCID: https://orcid.org/0000-0001-9808-1870,

e-mail: lyna.z858585@gmail.com

\section{С. В. Радченко,}

старший науковий співробітник лабораторії будівельно-технічних

досліджень Національного наукового центру «Інститут судових експертиз

ім. Засл. проф. М. С. Бокаріуса», м. Харків, Україна,

ORCID: https://orcid.org/0000-0003-1889-9061, e-mail: svet.radchenko@ukr.net

Н. В. Сила,

старший науковий співробітник лабораторії будівельно-технічних

досліджень Національного наукового центру «Інститут судових експертиз

ім. Засл. проф. М. С. Бокаріуса», м. Харків, Україна,

ORCID: https://orcid.org/0000-0003-3085-3082, e-mail: nata.syla@ukr.net

\section{ПРОБАЕМНІ ПИТАННЯ АОСАІАЖЕННЯ ПАНАУСІВ, ПРИЗНАЧЕНИХ ААЯ АОСТУПУ МААОМОБІАЬНИХ ГРУП НАСЕАЕННЯ АО БУАІВЕАЬ, ТА ВИЗНАЧЕННЯ ЇХ ВІАПОВІАНОСТІ БУАІВЕАЬНИМ НОРМАМ I ПРАВИААМ}

Визначено проблематику питань, щуо виникають під час проведення досліджень збудованих (реконструйованих) пандусів до наявних будівель, технічного переоснащцення ганків будівель та споруд або проєктів їх зведення щзодо відповідності будівельним нормам і правилам. Проведено візуальні обстеження та вимірювання геометричних параметрів понад 30 пандусів у різних районах міста Харкова.

Проаналізовано вимоги чинних будівельних норм, з'ясовано ступінь їх застосування до наявних споруд для доступу маломобільних груп населення до житлових і громадських будівель. Визначено й систематизовано основні види порушень будівельних норм та правил під час будівництва пандусів, щзо створюють значні перешкоди для доступу маломобільних груп населення до житлових і громадських будівель.

Ключові слова: адаптація, габаритні розміри, будівлі, споруди, громадські будівлі, елемент, житлові будинки, зона, маломобільні групи населення, особа з інвалідністю, доступність для маломобільних груп населення, (C) Ю. Ю. Петришина, С. В. Радченко, Н. В. Сила, 2020 
доступність для осіб з інвалідністю, інклюзивність будівель і споруд, місия обслуговування, пандус, підйом, розумне пристосування, фактура, илях руху.

Постановка наукової проблеми. Чинними державними будівельними нормами (далі - ДБН) України передбачено, що всі житлові та громадські будівлі, споруди мають бути спроєктовані та зведені з урахуванням потреб маломобільних груп населення, забезпечуючи їм доступність, зручність, інформативність і безпеку.

Однак, до сьогодні актуальна значна соціальна проблема, яка полягає в обмеженості доступу маломобільних груп населення (далі - МГН) до більшості наявних житлових і громадських будівель, споруд. Переважну кількість будівель старої забудови не обладнано відповідними архітектурно-будівельними елементами, що давали б змогу безпечно та зручно переміщатися житловою або громадською будівлею, а також безперешкодно входити туди й виходити звідти.

Технічне переоснащення наявних ганків житлових та громадських будівель, улаштування пандусів, тамбурів, входів, яке б забезпечувало фізичну можливість і зручність потрапляння до об'єкта й пересування ним або отримання послуг, найчастіше не відповідає вимогам ДБН В.2.2-40:2018 «ннклюзивність будівель та споруд. Основні положення» ${ }^{1}$.

Отже, відсутність або зведення будівельних конструкцій та елементів iз порушенням вимог ДБН нерідко цілком унеможливлює переміщення людей з обмеженими можливостями (передусім тих, хто пересувається на інвалідних візках), стають на заваді повноцінному життю та самостійному пересування, а також створюють небезпеку для здоров'я цієї категорії населення.

Під час попереднього вивчення цього питання було з'ясовано, що відсутні дослідження технічного стану архітектурно-будівельних елементів будівель для МГН, їх об'ємно-планувального й конструктивного рішення, зокрема пандусів та з’іздів, а також бракує джерел інформації з типологією та систематизацією найбільш поширених нормативних невідповідностей під час зведення подібних споруд. Це дослідження проведено методом візуального огляду пандусів та адаптованих ганків будівель у м. Харкові, їх конструктивних елементів, об'ємно-планувальних рішень і зіставленням здобутих результатів з вимогами нормативних документів. Також систематизовано найбільш поширені невідповідності й відхилення від наявних норм ДБН.

Подібне дослідження має на меті систематизувати інформацію 3 питання технічного стану наявних пандусів, адаптованих ганків у м. Харкові та Харківській області, щоб усунути визначені недоліки під час подальшого планування технічного переоснащення й удосконалення житлових

1 ДБН В.2.2-40:2018. Інклюзивність будівель та споруд. Основні положення. Чинний від 01.04.2019 p. URL: http://www.minregion.gov.ua/wp-content/ uploads/2019/01/V2240-2018.pdf (дата звернення: 03.06.2020). 
і громадських споруд — для безперешкодного пересування ними людьми з обмеженими можливостями.

Аналіз основних досліджень і публікацій. Лише останнім часом в Україні почали масово обладнувати входи до житлових і громадських споруд пандусами й адаптованими ганками. Тому відповідність збудованих (реконструйованих) пандусів до наявних будівель для доступу МГН раніше не досліджували, крім визначення нормативних вимог щодо них у ДБН В.2.2-40:2018 ${ }^{1}$ та ДБН В.2.2-9:2018 ${ }^{2}$.

Мета статті - дослідити методом аналізу об'ємно-планувальних і конструктивних рішень наявні пандуси та адаптовані ганки житлових будинків у м. Харкові, визначити їх технічний стан, відповідність будівельним нормам, а також систематизувати основні невідповідності вимогам ДБН під час зведення (реконструкції) пандусів або технічного переоснащення ганків для доступу МГН до приміщень житлових і громадських будівель. Розглянути основні питання, що виникають під час проведення досліджень 3 визначення відповідності збудованих (реконструйованих) пандусів або технічного переоснащення ганків будівель та споруд для можливості доступу МГН вимогам державних будівельних норм і правил.

Обгрунтувати рекомендації щодо необхідних змін у конструктивах наявних пандусів та адаптованих ганків житлових і громадських будівель для МГН з метою запобігання травмуванню, створення можливості для самостійного доступу до приміщень будівель та загального покращення умов життя людей $з$ обмеженими можливостями.

Викладення основного матеріалу дослідження. Дослідження архітектурно-будівельних рішень наявних пандусів та адаптованих ганків проведено за допомогою візуального огляду об'єктів у різних районах м. Харкова. Невідповідності будівельним нормам, виявлені під час огляду об'єктів, докладно розглянуто та проілюстровано фотографіями.

Рис. $1-8$ ілюструють типові приклади облаштування пандусів для доступу МГН шляхом проведення технічного переоснащення наявних ганків.

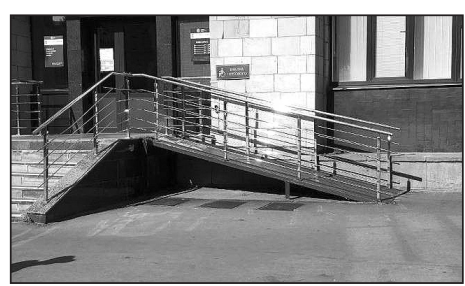

Рис. 1

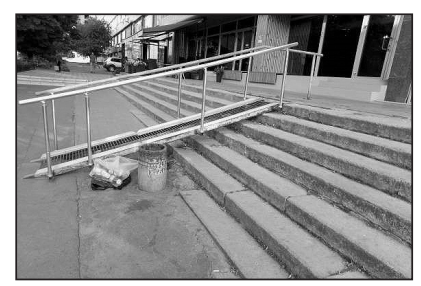

Рис. 2

${ }^{1}$ ДБН В.2.2-40:2018.

2 ДБН В.2.2-9:2018. Будинки і споруди. Громадські будинки та споруди. Основні положення. Чинний від 01.06.2019 p. URL: https:/dreamdim.ua/wp-content/ uploads/2019/03/DBN_V-2-2-9-2018-Gromadski-budynky.pdf (дата звернення: 03.06.2020). 
Рис. 1 - пандус улаштовано вздовж фасаду громадської будівлі зі зварних металевих конструкцій, поверхню пандуса заповнено рельєфним металевим листом, з обох боків пандуса встановлено збірне поруччя з неіржавної сталі. Металеві конструкції пофарбовано. Висота підйому пандуса складає 1,0 м. Рис. 2 - пандус улаштовано над наявними сходами громадської будівлі зі зварних металевих конструкцій, поверхню пандуса заповнено просічно-витяжною сіткою, з обох боків встановлено поручні з неіржавної сталі (кріплення бокові). Металеві конструкції пофарбовано, спостерігається ураження іржею по всій площині металевих конструкцій основи пандуса. Висота підйому пандуса - 0,9 м. Під час зведення пандусів, проілюстрованих світлинами 1 i 2, не дотримано такі вимоги ДБН В.2.2-40:2018 '

«5.3.1 Уклон зовнішніх пандусів на шляхах руху і біля входу до будівлі повинен бути не більше 8 \% (1:12), на коротких проміжках при перепаді висот поверхні на иляхах руху до 0,2 м і на з'їзді з тротуару на проїзну частину уклон приймається $10 \%$ (1:10) (рисунок 5). Ширина пандуса повинна бути в просвіті за однобічним рухом 1,2 м, за двобічним - 1,8 м. Максимальна висота одного підйому пандуса не повинна перевищувати 0,8 м. Після кожного підйому необхідне влаштовування горизонтальних площадок глибиною не менше 1,5 м. У виняткових випадках допускається передбачати гвинтові пандуси».

За висоти підйому пандусів 0,9 м та 1,0 м, зведених в один проліт, не дотримано значення нормативного уклону, отже, i довжини пандусів. Співвідношення габаритних розмірів пандусів (висоти й довжини для забезпечення нормативного уклону) проілюстровано на Рис. $3^{2}$.

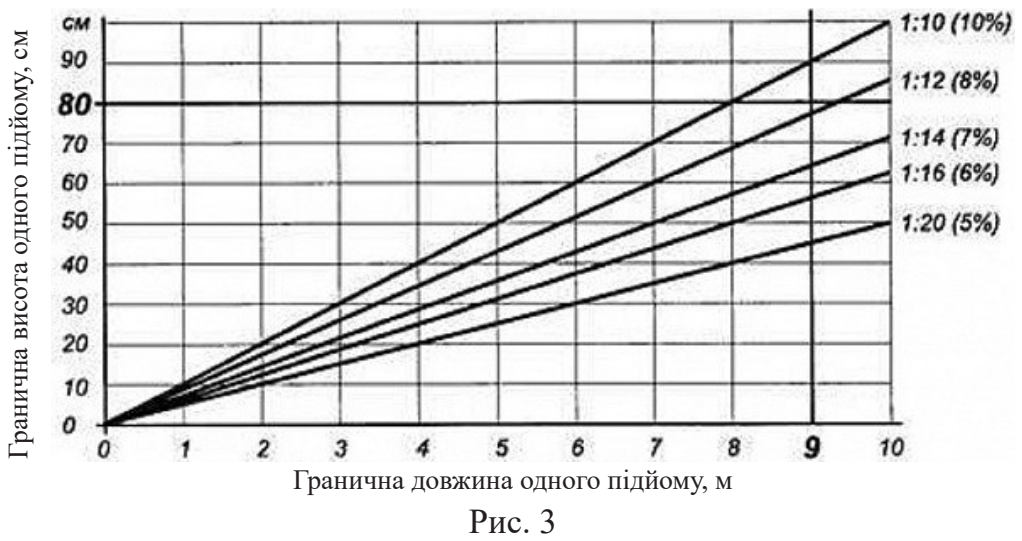

Окрім того, поручні пандуса (Рис. 2) мають бокові кріплення, що не відповідає вимогам п. 5.2.3 ДБН В.2.2-40:2018 3․

${ }^{1}$ ДБН В.2.2-40:2018.

${ }^{2}$ Уклон пандуса для инвалидов/Bouw.ru. URL: http://bouw.ru/article/uklonpandusa-dlya-invalidov (дата звернення: 03.06.2020).

${ }^{3}$ ДБН В.2.2-40:2018. 
«Сходи і пандуси повинні мати з обох боків поручні на висоті 0,7 м i 0,9 м, а в дошкільних закладах, парках, на дитячих майданчиках - додатково на висоті $0,5 \mathrm{M}$.

Поручень до опори має кріпитись знизу (не допускається бокове кріплення). Відстань від бічної стіни 0,045 м, діаметр труби поручня 0,0350,045 м. Завершальні частини поручня $і$ вгорі, і внизу повинні бути довщі мариу або похилої частини пандуса на 0,3 м та мати заокруглення.

За ширини сходів 2,5 м і більше слід додатково передбачати розділові поручні».

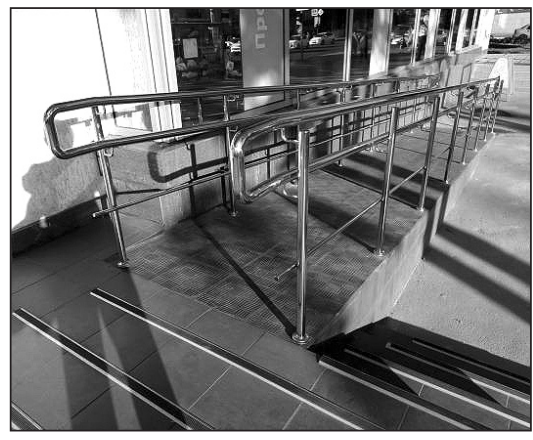

Рис. 4

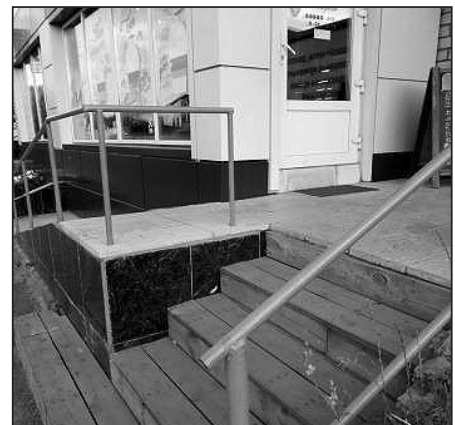

Рис. 5

Рис. 4 - пандус улаштований уздовж фасаду громадської будівлі, бетонний, облицьований керамогранітною плиткою, поверхню пандуса заповнено бетонною плиткою, обабіч пандуса встановлено збірне поруччя 3 нержавіючої сталі. Ширина пандуса з урахуванням поручнів складає 1,2 м. Під час зведення пандуса, проілюстрованого світлиною 3, не дотримано такі вимоги п. 5.3.1 ДБН В.2.2-40:2018 ${ }^{1}$ : «Ширина пандуса повинна бути в просвіті за однобічним рухом 1,2 м, за двобічним - 1,8 м».

Рис. 5 - пандус улаштований уздовж фасаду громадської будівлі, бетонний, облицьований під мармур, поверхня пандуса — бетонна стяжка. Із зовнішнього боку пандуса встановлено зварне металеве поруччя, пофарбоване олійною фарбою. Глибина горизонтального майданчика пандуса складає 0,7 м. Висота порогу вхідних дверей - 0,12 м. Під час зведення пандуса, проілюстрованого світлиною 4, не дотримано такі вимоги ДБН B.2.2-40:2018 ${ }^{2}$ :

«5.3.1 < ..> Після кожного підйому необхідне влаштування горизонтальних площадок глибиною не менш ніж 1,5 м. < ..>

$<\ldots>$

6.1.4 Вхідні двері необхідно проєктувати без порогів. За необхідністю влаштування порогів висота кожного елемента порога не повинна перевищувати 0,02 м. $<\ldots>$ ».

\footnotetext{
1 ДБН В.2.2-40:2018.

2 там само.
} 


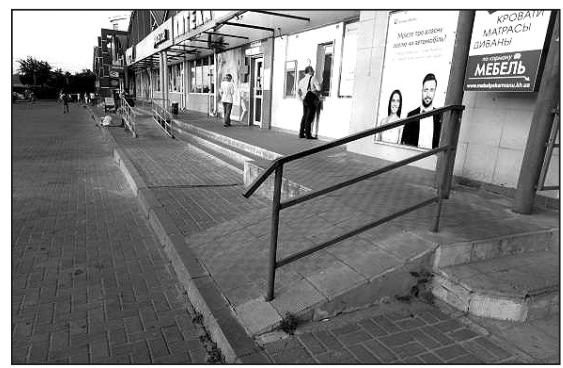

Рис. 6

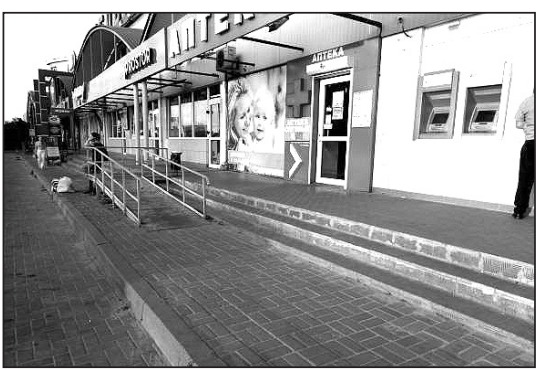

Рис. 7

Рис. 6 - пандус улаштовано перпендикулярно фасаду громадської будівлі, він виходить на паркінг, бетонний, оштукатурений, поверхню пандуса заповнено бетонною плиткою, з одного боку пандуса встановлено зварне металеве поруччя прямокутного перерізу, пофарбоване олійною фарбою. Облаштування з'їзду на паркінг у місці визначення бордюру не виконано, доступ до пандуса обмежено. Під час зведення пандуса, проілюстрованого світлиною 5, не дотримано такі вимоги ДБН В.2.2-40:2018 '

«5.1.6 За неможливості організаиії наземних пімохідних переходів $<$...> необхідно проєктувати підземні та надземні переходи, які слід обладнувати пандусами з пологим спуском або підйомними пристроями (ліфт, підйомник).

$<\ldots>$

5.3.2 Зовнішні пандуси повинні мати двобічну огорожу з поручнями $<\ldots>$ ».

Рис. 7 - пандус улаштовано вздовж фасаду громадської будівлі зі зварних металевих конструкцій, поверхню пандуса заповнено рельєфним металевим листом, обабіч пандуса встановлено зварне металеве поруччя прямокутного перерізу (кріплення бокові), пофарбоване олійною фарбою. Спостерігається ураження іржею по всій площині поверхні заповнення пандуса. Облаштування з'їзду на паркінг у місці визначення бортового каменю не виконано, доступ до пандуса обмежено. Під час зведення пандуса, проілюстрованого світлиною 6, не дотримано такі вимоги ДБН В.2.2-40:2018 22:

«5.1.6 За неможливості організачії наземних пішохідних переходів $<. .>$ необхідно проєктувати підземні та надземні переходи, які слід обладнувати пандусами з пологим спуском або підйомними пристроями (ліфт, підйомник).

$<\ldots>$

5.2.3 Сходи і пандуси повинні мати з обох боків поручні на висоті 0,7 . i 0,9 м, а в дошкільних закладах, парках, на дитячих майданчиках - додатково на висоті 0,5 $\mathrm{M}$.

\footnotetext{
${ }^{1}$ ДБН В.2.2-40:2018.

2 Там само.
} 
Поручень до опори має кріпитись знизу (не допускається бокове кріплення). Відстань від бічної стіни 0,045 м, діаметр труби поручня 0,0350,045 м. Завершальні частини поручня $і$ вгорі, і внизу повинні бути довщі маршу або похилої частини пандуса на 0,3 м та мати заокруглення.

За ширини сходів 2,5 м і більше слід додатково передбачати розділові поручні».

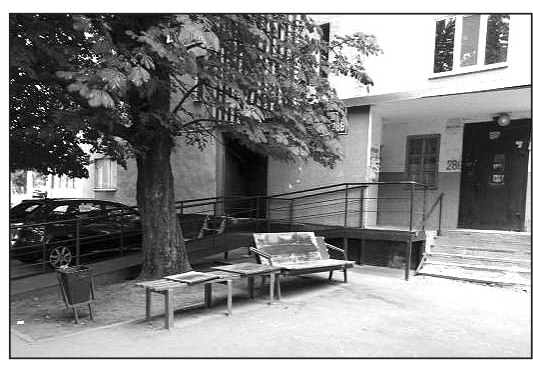

Рис. 8

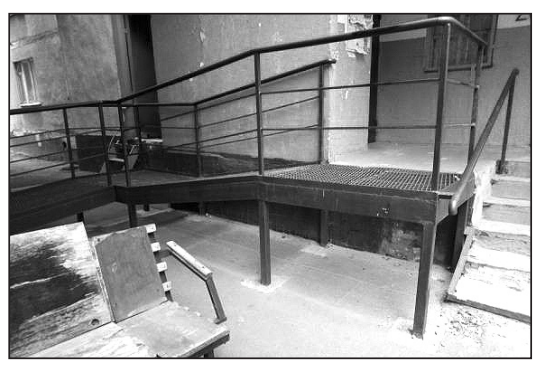

Рис. 9

Рис. 8 і 9 - пандус улаштовано вздовж фасаду багатоповерхового житлового будинку зі зварних металевих конструкцій, поверхню пандуса заповнено просічно-витяжною сіткою, обабіч пандуса встановлено зварне металеве поруччя прямокутного перерізу. Металеві конструкції пофарбовано. Глибина горизонтального майданчика пандуса складає 1,4м. Ширина пандуса з урахуванням поруччя - 1,0 м. Під час зведення пандуса, проілюстрованого світлинами 7 і 8, не дотримано такі вимоги, зазначені в п. 5.3.1 ДБН В.2.2-40:2018 ${ }^{1}$ :

«Ширина пандуса повинна бути в просвіті за однобічним рухом 1,2 м, за двобічним - 1,8 м. Максимальна висота одного підйому пандуса не повинна перевищувати 0,8 м. Після кожного підйому необхідне влаштування горизонтальних площяадок глибиною не менш ніж 1,5 м».

Крім того, у всіх наведених вище прикладах улаштування пандусів має місце суттєва невідповідність нормативним вимогам, яка полягає в тому, що над майданчиками й пандусами не влаштовано навісів, що також передбачено ДБН В.2.2-40:2018 2:

«5.1.11 Вхідна площадка будівлі повинна мати: навіс, водовідвід як з поверхні площадки, так із покриття навісу. Залежно від місиевих кліматичних умов підігрів площцадки слід встановлювати за завданням на проєктування.

$<\ldots>$

5.3.3 Необхідність підігріву поверхні пандуса, а також улаштування навісу або укриття визначається завданням на проєктування».

\footnotetext{
${ }^{1}$ ДБН В.2.2-40:2018.

2 там само.
} 
Крім того, ДБН В.2.2-9:2018 ${ }^{1}$ передбачає, що проєктні рішення, пристрої та заходи мають бути зручними для всіх груп користувачів (зокрема, МГН) без додаткових адаптувань і пристосувань. У разі неможливості ухвалити універсальні рішення, слід послуговуватися розумними пристосуваннями для МГН відповідно до ДБН В.2.2-40 2 ${ }^{2}$ Потрібно передбачити безперешкодне та зручне переміщення осіб з інвалідністю й інших МГН громадськими будівлями, установами, закладами чи підприємствами.

Також слід зауважити, що під час проведення робіт з технічного переоснащення (реконструкції) наявних ганків під потреби МГН власники або орендарі громадських будівель мають отримати дозвіл на відвід земельної ділянки під будівництво, технічне завдання на проєктування, розробити проєктну документацію й отримати дозвільні та погоджувальні документи в органах місцевого самоврядування. Виконання цих заходів потребує значних витрат часу.

Під час проведення дослідження (в обсязі наведених прикладів) з'ясовано, що визначені невідповідності можна об'єднати у дві групи: перша невідповідності, які можливо усунути шляхом переобладнання та приведення пандусів до вимог ДБН (пандусів, наведених на фотографіях 5 і 6; а саме: улаштування з'їздів на тротуар, правильного розміщення та заміни поруччя); друга - невідповідності, які усунути неможливо, адже в такому разі доведеться змінювати конструктивні й об'ємно-планувальні рішення (пандуси, наведені на фотографіях 1—4, 7 і 8; де виявлено невідповідності за шириною та висотою пандусів, глибиною горизонтальних майданчиків, незабезпеченню нормативного уклону та інші недоліки, які можна усунути тільки шляхом повної заміни).

Висновки. Розглянуто й систематизовано найпоширеніші невідповідності вимогам ДБН, які зустрічаються під час зведення (реконструкції) пандусів або технічного переоснащення ганків для доступу МГН до приміщень житлових і громадських будівель. Крім того, надано рекомендації щодо усунення виявлених невідповідностей залежно від їх характеру. Отже, проаналізувавши наведені у цій статті матеріали, а також рівень розвитку соціальної інфраструктури міста, ми дійшли висновку, що більшість житлових і громадських будівель не задовольняють потреб МГН та потребують удосконалення. Тема проведення дослідження $є$ актуальною, повною мірою розкриває вирішувані проблемні питання й може стати в пригоді під час проведення будівельно-технічних експертиз та експертних досліджень як інформативне джерело.

\section{References}

DBN V.2.2-40:2018. Inkliuzyvnist budivel ta sporud. Osnovni polozhennia. Chynnyi vid 01.04.2019 r. URL: http://www.minregion.gov.ua/wp-content/uploads/2019/01/ V2240-2018.pdf (data zvernennia: 03.06.2020) [in Ukrainian].

\footnotetext{
1 ДБН В.2.2-9:2018.

${ }^{2}$ ДБН В.2.2-40:2018.
} 
DBN V.2.2-9:2018. Budynky i sporudy. Hromadski budynky ta sporudy. Osnovni polozhennia. Chynnyi vid 01.06.2019 r. URL: https:/dreamdim.ua/wp-content/ uploads/2019/03/DBN_V-2-2-9-2018-Gromadski-budynky.pdf (data zvernennia: 03.06.2020) [in Ukrainian].

Uklon pandusa dlia ynvalydov. Bouw.ru. URL: http://bouw.ru/article/uklon-pandusa-dlya-invalidov (data zvernennia: 03.06.2020) [in Ukrainian].

Ю. Ю. Петришина, С. В. Радченко, Н. В. Сила

ПРОБЛЕМНЫЕ ВОПРОСЫ ИССЛЕДОВАНИЯ

ПАНДУСОВ, ПРЕДНАЗНАЧЕННЫХ ДЛЯ ДОСТУПА

МАЛОМОБИЛЬНЫХ ГРУПП НАСЕЛЕНИЯ В ЗДАНИЯ, И ОПРЕДЕЛЕНИЯ ИХ СООТВЕТСТВИЯ СТРОИТЕЛЬНЫМ НОРМАМ И ПРАВИЛАМ

Определена проблематика вопросов, возникающих при исследовании возведённых (реконструированных) пандусов к сущеествующим зданиям, технического переоснащения крылец зданий и сооружений или проектов их строительства на предмет соответствия строительным нормам и правилам. Проведено визуальное обследование планировочных и конструктивных решений, выполнены замеры геометрических параметров более 30 пандусов в разных районах города Харькова.

Проанализованы требования действующих строительных норм, установлена степень их применения к существующим сооружениям для доступа маломобильных групп населения в жилье и общественные здания. Установлены и систематизированы основные виды нарушений строительных норм и правил при строчтельстве пандусов, создающих значительные препятствия для доступа маломобильных групп населения в жилье и общуественнные здания. Даны рекомендации относительно необходимых изменений в конструкции пандусов и адаптированных крылеи жильх и общественных зданий с целью предотвращения травмирования МГН.

Ключевые слова: адаптация, габаритные размеры, здания, сооружения, общественные здания, элемент, жилье здания, зона, маломобильные группь населения, особа с инвалидностью, доступность для маломобильных групп населения, доступность для лии с инвалидностью, инклюзивность зданий и сооружений, места обслуживания, пандус, подъём, разумное приспособление, фактура, путь движения.

Yu. Petryshyna, S. Radchenko, N. Syla

COMPLEX ISSUES ARISING WHILE CONDUCTING RESEARCH

ON WHEELCHAIR RAMPS FOR ACCESS TO BUILDINGS BY PERSONS WITH REDUCED MOBILITY AND

DETERMINATION OF WHEELCHAIR RAMPS' COMPLIANCE WITH BUILDING STANDARDS AND REGULATIONS

The article outlines issues which arise when conducting research on wheelchair (reconstructed) ramps of existing buildings, technical re-equipment of building porches and buildings or their construction projects for compliance 
with building standards and regulations. As a method of research we have chosen visual inspection of construction and planning solutions, namely measuring of geometric parameters of over 30 ramps in different districts in the city of Kharkiv has been conducted.

Requirements of current building regulations are analyzed, their applicability to public and residential buildings for access by persons with reduced mobility is established. Main types of violations of building standards and regulations while construction of ramps, which create significant obstacles for people with limited mobility to access residential and public buildings, have been identified and systematized. Recommendations are provided regarding the possibility of making necessary changes in the design of ramps and adapted porches of residential and public buildings in order to prevent injury to persons with reduced mobility.

Keywords: adaptation, overall dimensions, accessibility of buildings and facilities for people with reduced ability, public buildings, accessibility for persons with disability, element, residential buildings, zone, inclusion of buildings and facilities, persons with reduced mobility, person with disability, wheelchair ramp, a ramp slope, reasonable accommodation, surface coating, trajectory of movement.

Надійшла до редколегії 17.06.2020

Петришина Ю. Ю., Радченко С. В., Сила Н. В. Проблемні питання дослідження пандусів, призначених для доступу маломобільних груп населення до будівель, та визначення їх відповідності будівельним нормам і правилам. Теорія та практика судової експертизи і криміналістики : зб. наук. пр. / редкол.: О. М. Клюєв, В. Ю. Шепітько та ін. Харків : Право, 2020. Вип. 22. С. 406-415. DOI: https:// doi.org/10.32353/khrife.2.2020.33. 